\title{
PENGGUNAAN LEMBAR KERJA SISWA (LKS) UNTUK MENINGKATKAN HASIL BELAJAR BIOLOGI SISWA KELAS XI SMAN 8 PEKANBARU
}

\author{
Asnitawati \\ Guru SMA Negeri 8 Pekanbaru_ \\ asnitawati_tp_2009@yahoo.com
}

\begin{abstract}
ABSTRAK: Hasil belajar biologi siswa di kelas XI semester genap belum memperlihatkan hasil yang optimal pada materi yang membahas fungsi fisiologis organ-organ tubuh manusia. Dari hasil observasi diperoleh data bahwa pada proses pembelajaran guru menggunakan Lembar Kerja Siswa yang disusun oleh Musyawarah Guru Mata Pelajaran (MGMP), belum menggunakan pendekatan santifik. Hal inilah yang memicu penulis untuk melakukan penelitian tindakan kelas yang bertujuan untuk meningkatkan hasil belajar biologi siswa di kelas XI dengan menggunakan Lembar Kerja Siswa (LKS) berbasis student centered Learning. Lembar Kerja Siswa (LKS) berbasis student centered disusun sedemikian rupa agar memenuhi pembelajaran pendekatan saintifik dengan menggunakan langkah 5 M. Prosedur penelitian tindakan kelas ini menggunakan dua siklus, akhir dari setiap siklus dilakukan ulangan harian siswa untuk melihat peningkatan hasil belajar yang terjadi. Setelah tindakan siklus I diperoleh rerata hasil belajar siswa sebesar 71,47, dan mengalami peningkatan pada siklus II menjadi 76,31, maka dapat disimpulkan bahwa penggunaan Lembar Kerja Siswa (LKS) berbasis student centered learning dapat meningkatkan hasil belajar biologi siswa kelas XI SMA Negeri 8 Pekanbaru.
\end{abstract}

Kata kunci: Lembar Kerja Siswa, student centered learning, hasil belajar 


\title{
THE USE OF STUDENTS WORKSHEET TO IMPROVE BIOLOGY LEARNING RESULT OF THE SECOND YEAR STUDENTS OF SMAN 8 PEKANBARU
}

\begin{abstract}
Biology learning results of students in class XI have not shown optimal on material that discusses the physiological functions of human organs. From the observations obtained data that the teacher learning process using Student Worksheets prepared by the Subject Teachers' Consultation (MGMP), has not used the scientific approach. This has triggered the writer to conduct classroom action research aimed to improve students biology learning results in class XI by using worksheets based on Student Centered Learning are arranged in such a way as to meet the learning approach of science using step $5 \mathrm{M}$. This class action research procedure used two cycles, at the end of each cycle the students' daily tests are performed to see the increase in learning results that occur. After the cycle I action, the average student learning results were 71.47, and it increased in cycle II to 76.31, so it can be concluded that the use of Student Worksheets Based on Student Centered Learning can improve the biology learning results of the second year students of SMA Negeri 8 Pekanbaru.
\end{abstract}

Keywords: Student Worksheets, student centered learning, learning results

\section{PENDAHULUAN}

Pembelajaran pada kurikulum 2013 untuk semua jenjang dilaksanakan menggunakan pendekatan saintifik yaitu pendekatan pembelajaran yang berpusat pada peseta didik menekankan pada dimensi pedagogi modern dalam pembelajaran, yaitu menggunakan pendekatan ilmiah. Pendekatan ilmiah ini melibatkan peserta didik ke dalam serangkaian kegiatan ilmiah yang terdiri atas lima pokok, yaitu mengamati, menanya, mengumpulkan data / eksperimen, mengasosiasi / menalar, dan mengkomunikasikan (Permendikbud, 2013). Pendekatan ilmiah akan memberi pengaruh pada perkembangan potensi diri yang dimiliki peserta didik.

Pembelajaran yang berpusat pada siswa atau Student Center Learning (SCL) memerlukan LKS (Lembar Kerja Siswa) dalam proses pembelajarannya. Menururt Amalia Rif'atus Sulcha, dkk (2013), dalam pelaksanaannya di sekolah, pembelajaran dengan melibatkan peran aktif siswa dapat ditunjang dengan menggunakan LKS yang dapat memfasilitasi untuk membangun keterampilan prosesnya. Dengan demikian siswa dituntut untuk lebih aktif menggali pengetahuannya dengan cara mencari sumber belajar dan informasi yang tepat terkait materi pembelajaran, untuk mendukung siswa 
meningkatkan prestasi belajarnya dibutuhkan bahan ajar. Adapun sumber belajar yang harus dikembangkan oleh guru berupa Lembar Kerja Siswa (LKS) yang dapat digunakan sebagai acuan dalam pelaksanaan kegiatan pembelajaran di sekolah, selain itu dapat dijadikan latihan-latihan terbimbing. Sejalan dengan Fahrie (2012) lembar kerja siswa mempunyai fungsi salah satunya LKS digunakan untuk memotivasi siswa ketika melakukan tugas latihan sehingga siswa terdorong untuk belajar lebih giat secara mandiri.

Dari data ulangan harian siswa kelas XI pada materi fisiologi seperti sistem sirkulasi, sistem gerak pencernaan, respirasi, dan ekskresi diperoleh data siswa yang tuntas sudah lebih dari $70 \%$. Suatu permasalahan muncul setelah penulis amati adalah terdapat $75 \%$ siswa memperoleh nilai pada kisaran 73-78, sisanya siswa memperoleh nilai tuntas pada interval 79-85. Tidak ada siswa yang memperoleh nilai di atas 85-100. Hal ini menunjukkan bahwa hasil belajar yang diperoleh siswa belum mengalami pencapaian yang optimal.

Berdasarkan hasil analisis, lembar kerja siswa yang disusun oleh MGMP belum mencerminkan proses saintifik yaitu tidak adanya proses melakukan pengamatan, menanya, mencoba, menalar dan mengkomunikasikan. Lembar Kerja Siswa yang disusun oleh MGMP juga belum dapat mencapai keseluruhan tuntutan dari kurikulum, karena ada beberapa submateri yang tidak tercantum pada lembar kerja tersebut. Kurang baiknya kualitas LKS yang digunakan menyebabkan siswa menjadi tidak terarah untuk memahami materi pembelajaran. Pembelajaran menjadi kurang efektif dan membosankan. Butir-butir pertanyaan yang ada di LKS tidak mampu mengajarkan siswa untuk menemukan konsep dari materi yang sedang dipelajari oleh mereka sendiri dan gambar serta penampilan di dalam LKS kurang menarik ditambah guru hanya berceramah dengan menggunakan slide presentasi lalu memberikan soal-soal secara lisan kepada siswa untuk dikerjakan siswa secara individu maupun berkelompok.

\section{KAJIAN PUSTAKA}

Pendekatan pendidikan SCL (Stu-dent Centered Learning) muncul sebagai alternative pendekatan pendidikan untuk menjawab permasalahan ketidaksesuaian pendekatan TCL. SCL merupakan pendekatan pembelajaran yang berpusat pada siswa. Dalam pendekatan pembelajaran SCL, guru harus mampu melaksanakan perannya dengan baik yaitu tidak hanya sebagai pengajar, tetapi juga sebagai motivator, fasilitator, dan inovator. Guru tidak hanya dituntut untuk mengajar saja di depan kelas melainkan juga 
berperan membantu murid untuk memecahkan masalah saat murid mengalami kesulitan dalam proses pembelajaran. Natawijaya dalam Depdiknas (2005:31) menyebutkan bahwa belajar aktif adalah suatu sistem belajar mengajar yang menekankan keaktifan siswa secara fisik, mental intelektual dan emosional guna memperoleh hasil belajar berupa perpaduan antara aspek kognitif, afektif dan psikomotor.

Maryam Nur Azizah melakukan pe-nelitian pada tahun 2011 terhadap "Efek-tivitas Penggunaan Metode Pembelajaran Student Centered Learning Berbasis Class-room Blogging Untuk Meningkatkan Hasil Belajar Siswa SMA". Penelitian ini mem-bandingkan antara kelas yang mengguna-kan metode pembelajaran Student Center-ed Learning berbasis Classroom Blogging dan kelas yang menggunakan metode kon-vensional. Penelitian yang dilaksanakan memperoleh kesimpulan bahwa proses pembelajaran yang menggunakan metode pembelajaran Student Centered Learning memperoleh peningkatan hasil belajar yang lebih tinggi (Azizah, 2011).

SCL merupakan strategi pembelajaran yang menempatkan peserta didik (subyek) aktif dan mandiri, dengan kondisi psikologik sebagai adult learner, bertanggung jawab sepenuhnya atas pembelajarannya, serta mampu belajar beyond the classroom. Kelak, peserta didik diharapkan memiliki dan menghayati karakteristik lifelong learning yang menguasai hard skills, soft skills, dan life-skills yang saling mendukung. Di sisi lain, para guru beralih fungsi, dari pengajar menjadi mitra pembelajaran maupun sebagai fasilitator (from mentor in the center to guide on the side).

Terlaksananya pendekatan saintifik K13 sangat ditunjang oleh kreatifitas guru sebagai motivator dan fasilitator di dalam kelas, untuk itu guru dituntut mempunyai alat bantu dalam pembelajaran seperti dengan menggunakan LKS yang berbasis Student Centered Learning (SCL). Lembaran Kerja Siswa yang berbasis SCL dapat menggiring siswa untuk melakukan kegiatan pembelajaran secara saintifik dengan 5 tahapan, yaitu: Mengamati (Observing), menanya (Questioning), Mengumpulkan Informasi/mencoba (Experimenting), Menalar/Mengasosiasi, dan Mengomunikasikan.

Dari penjelasan 5 tahapan saintifik di atas, jelas bahwa dituntut peran aktif guru agar proses pembelajaran berjalan seperti yang diharapkan dengan berpusat kepada siswa atau student centered learning. Salah satu usaha agar pendekatan saintifik dapat berlangsung Lembar Kerja Siswa (LKS) berbasis student centered learning dapat digunakan guru. Penggunaan LKS berbasis Student Centered Learning dapat dilakukan guru dengan beberapa langkah kegiatan, yaitu :

Pertama, pembentukan kelompok. Guru membagi siswa menjadi beberapa kelompok, pembentukan kelompok bisa guru yang menentukan atau murid sendiri yang 
menentukan. Kelompok yang sudah terbentuk akan diberi petunjuk atau kisi-kisi untuk memecahkan masalah yang ada di LKS, kemudian menemukan jawaban terkait proses pembelajaran.

Kedua, pemberian tugas. Guru memberikan kisi-kisi materi dan pertanyaan (tugas) kepada siswa sesuai materi pembelajaran. Tugas ini bisa didiskusikan dengan kelompok atau mencari sumber untuk mencari jawaban. Hasil akhir dari tugas bisa dalam bentuk presentasi, bermain peran, mindmap, paper ataupun peta (gambar) sesuai dengan materi serta tugas pembelajaran.

Ketiga, eksplorasi. Siswa bersama kelompoknya melakukan diskusi, wawancara pada narasumber, mencari materi tugas melalui internet untuk menyelesaikan tugas, dan siswa melakukan praktikum untuk menemukan sendiri jawaban dari suatu permasalahan.

Keempat, presentasi. Presentasi dilaksanakan untuk menyampaikan hasil temuan jawaban atau kesimpulan suatu materi pembelajaran, salah satu anggota kelompok maju menjelaskan jawabannya.

Depdiknas dalam Darusman (2008), menyatakan bahwa LKS adalah lembaran yang berisikan pedoman bagi siswa untuk melaksanakan kegiatan yang terprogram. Sedangkan Shadiq dalam Andayani (2005), mendefinisikan LKS sebagai lembaran duplikat yang dibagikan guru kepada siswa di suatu kelas untuk melakukan kegiatan atau aktivitas belajar mengajar. Lembaran ini berisi petunjuk, tuntunan pertanyaan dan pengertian agar siswa dapat memperluas serta memperdalam pemahamannya terhadap materi yang dipelajari.

Lembar Kerja Siswa (LKS) merupakan salah satu jenis alat bantu pembelajaran, bahkan ada yang menggolongkan dalam jenis alat peraga pembelajaran biologi. Secara umum LKS merupakan perangkat pembelajaran sebagai pelengkap atau sarana pendukung pelaksanaan Rencana Pelaksanaan Pembelajaran (RPP). Lembar kerja siswa berupa lembaran kertas yang berupa informasi maupun soal-soal (pertanyaan-pertanyaan) yang harus dijawab oleh peserta didik. LKS ini sangat baik digunakan untuk menggalakkan keterlibatan peserta didik dalam belajar baik dipergunakan dalam penerapan metode terbimbing maupun untuk memberikan latihan pengembangan. Dalam proses pembelajaran biologi, LKS bertujuan untuk menemukan konsep atau prinsip dan aplikasi konsep atau prinsip (Farid, 2010).

\section{METODE PENELITIAN}

Penelitian ini merupakan Penelitan Tindakan Kelas yang dirancang dalam dua siklus dengan 4 kali pertemuan pada masing-masing siklus. Ciri khas dari Penelitian Tindakan Kelas adalah terdiri dari 4 tahapan, yaitu : perencanaan, pelaksanaan, pengamatan dan 
refleksi. Tindakan yang dilakukan dalam penelitian ini, yaitu dengan menggunakan Lembar Kerja Siswa berbasis Student Centered Learning yang dilaksanakan pada semester genap pada bulan Januari sampai dengan Maret 2014.

\section{Instrumen Penelitian}

Instrumen yang digunakan untuk mengukur hasil belajar siswa, berupa tes yang dilakukan pada akhir siklus. Setiap akhir siklus 1 dan 2 dilakukan ulangan harian dengan menggunakan indikator sesuai materi. Tes yang dilakukan menggunakan soal pilihan ganda sebanyak 30 soal.

\section{Teknik Pengumpulan Data}

Data yang dikumpulkan dari penelitian yang diperoleh dari tes hasil belajar kepada siswa setiap akhir siklus. Pelaksanaan tes hasil belajar siswa didalam kelas dibantu oleh teman sejawat untuk mengawasi dan memeriksa hasil belajar siswa yang dilakukan setiap akhir siklus. Hasil belajar atau tes yang dilakukan setelah penyampaian materi untuk setiap akhir siklus.

\section{Teknik Analisis Data}

Teknik analisis data yang dilakukan adalah dengan analisis secara deskriptif terhadap hasil belajar dengan pemberian tes. Analisis ini bertujuan untuk melakukan tindakan perbaikan yang dilakukan pada siklus selanjutnya. Tes hasil belajar Biologi diukur melalui tes objektif (bentuk pilihan ganda), kemudian skor diberi nilai rentang skala 1-100. Pengskoran tes pilihan ganda menggunakan rumus Arief, dkk. (1989:265) yaitu:

$$
\mathrm{S}=\frac{\mathrm{JB}}{\mathrm{JS}} \times 100
$$

Keterangan :

$$
\mathrm{S}=\text { Skor }
$$

$\mathrm{JB}=$ Jumlah betul

$\mathrm{JS}=$ Jumlah salah

Indikator keberhasilan tindakan terhadap peningkatan hasil belajar siswa dengan cara sebagai berikut:

a. Membandingkan tingkat keberhasilan dari satu siklus ke siklus berikutnya, keberhasilan tindakan pada siklus I diketahui dengan membandingkan nilai minimal 73 dan observasi kolaborator keberhasilan tindakan pada siklus II.

b. Indikator kriteria keberhasilan tindakan ditentukan oleh peneliti, dengan kriteria apabila siswa menunjukkan hasil belajar diatas nilai 73 dan peningkatan hasil belajar secara 
kelompok ditetapkan apabila dari jumlah siswa 1(satu) kelas lebih dari $70 \%$ mendapatkan nilai minimal 73 .

\section{HASIL PENELITIAN DAN PEMBAHASAN}

\section{Siklus 1}

Pelaksanaan untuk siklus I dimulai tanggal 07 januari 2014 dengan pertemuan sebanyak 5 kali yakni 4 kali pertemuan untuk materi tatap muka dan satu kali untuk pelaksanaan tes siklus I. Data observasi yang diperoleh dari hasil tes belajar siklus I pada kelas XI IPA5 semester ganjil dengan tes tertulis melalui tes pilihan ganda berjumlah 30 soal. Hasil belajar yang diperoleh siswa pada siklus I yang diberikan oleh guru, adalah sebagai berikut:

Tabel 1. Hasil Belajar Siswa Siklus I

\begin{tabular}{llc}
\hline No & \multicolumn{1}{c}{ Hasil Belajar } & Pencapaian Siklus I \\
\hline 1 & Nilai Terendah & 50 \\
2 & Nilai Tertinggi & 100 \\
3 & Nilai Rata-rata kelas & 71,47 \\
4 & Jumlah siswa > nilai 73 & 18 orang \\
5 & Jumlah siswa & 32 orang \\
6 & Presentase Mendapat Nilai $\geq 73$ & $56,25 \%$ \\
\hline
\end{tabular}

Hasil belajar siswa pada siklus I seperti yang terlihat pada tabel 1 menunjukkan bahwa jumlah siswa yang mempunyai nilai diatas 73 hanya 56,25\%. Berikut sebaran siswa untuk masing-masing nilai pada siklus I.

Tabel 2. Sebaran siswa untuk masing-masing nilai pada siklus I

\begin{tabular}{llcc}
\hline No & Range Nilai & Jumlah & $\begin{array}{c}\text { Siswa } \\
\text { Persentase }\end{array}$ \\
\hline nilai $>85$ & 4 & $12,5 \%$ \\
$75<$ nilai $\leq 85$ & 14 & $43,75 \%$ \\
$65<$ nilai $\leq 75$ & 9 & $28,13 \%$ \\
$55<$ nilai $\leq 65$ & 5 & $15,63 \%$ \\
nilai $<55$ & - & -
\end{tabular}


$100,00 \%$

Berdasarkan hasil belajar dan penilaian terhadap tes siklus I, diperoleh bahwa:

1. Pelaksanaan pembelajaran penggunaan Lembar Kerja Siswa berbasis Student Centered Learning pada pembelajaran Biologi dengan pendekatan saintifik discoveri pada siklus I ini siswa mempunyai nilai rata-rata 71,47.

2. Pembelajaran penggunaan Lembar Kerja Siswa berbasis Student Centered Learning dengan inkuiri pada pembelajaran Biologi yang mendapatkan nilai $\geq 73$ hanya 56,25\%.

\section{Siklus 2}

Proses pembelajaran pada siklus II, secara keseluruhan berdasarkan pengamatan guru dari pertemuan kesatu hingga pertemuan keempat guru dan siswa sudah terbiasa dengan pengalaman pembelajaran yang menggunakan Lembar Kerja Siswa berbasis Student centered Learning dengan pendekatan saintifik discoveri sehingga suasana belajar menjadi kondusif dan berjalan dengan lancar. Guru mengamati tidak ada masalah yang berarti dalam semua tahapan yang berlangsung saat pembelajaran.

Tes hasil belajar siswa yang dilakukan diakhir siklus II, diperoleh data sebagai berikut :

Tabel 3. Hasil Belajar siswa Siklus II

\begin{tabular}{clc}
\hline No & \multicolumn{1}{c}{ Hasil Tes } & Pencapaian Siklus II \\
\hline 1 & Nilai Terendah & 60 \\
2 & Nilai Tertinggi & 100 \\
3 & Nilai Rata-rata kelas & 76,31 \\
4 & Jumlah siswa > nilai 73 & 30 orang \\
5 & Jumlah siswa & 32 orang \\
6 & Presentase Mendapat Nilai $\geq 73$ & $87,5 \%$ \\
\hline
\end{tabular}

Tabel diatas memperlihatkan jumlah siswa yang telah mendapat nilai > 75 sebanyak 30 orang dari 32 orang siswa atau sebesar 87,5\% mendapat nilai minimal 75. Hasil belajar siswa pada siklus II dapat dikelompokkan menurut sebaran nilai dengan huruf sebagai berikut : 
Tabel 4. Sebaran Siswa untuk Masing-masing Nilai pada Siklus II

\begin{tabular}{rccc}
\hline \multirow{2}{*}{ No } & Range Nilai & \multicolumn{2}{c}{ Siswa } \\
\cline { 2 - 4 } & nilai $>85$ & 10 & Persentase \\
\hline $75<$ nilai $\leq 85$ & 18 & $31,25 \%$ \\
$65<$ nilai $\leq 75$ & 4 & $56,25 \%$ \\
$55<$ nilai $\leq 65$ & - & $12,5 \%$ \\
nilai $<55$ & - & - \\
TOTAL $:$ & 32 & - \\
\hline
\end{tabular}

Berdasarkan hasil belajar dan penilaian terhadap tes siklus II, diperoleh bahwa:

a Pelaksanaan pembelajaran penggunaan Lembar Kerja Siswa berbasis Student Centered Learning dalam pembelajaran Biologi dengan dengan pendekatan saintifik discoveri pada siklus II ini siswa mempunyai nilai rata-rata 76,31.

b. Pembelajaran penggunaan dengan metode inkuiri dalam pembelajaran Biologi yang mendapatkan nilai $\geq 73$ hanya $87,5 \%$.

Dari hasil belajar siklus II, menunjukkan bahwa nilai siswa dengan yang mendapat nilai 73 sudah lebih dari $80 \%$, maka dapat disimpulkan bahwa pembelajaran Biologi menggunakan Lembar Kerja Siswa berbasis Student Centered Learning dengan pendekatan saintifik discoveri pada penelitian ini sudah cukup memadai sampai pada tindakan siklus II saja.

Hasil belajar siklus II, hasil belajar yang diperoleh dalam siklus II terlihat bahwa penggunaan Lembar Kerja Siswa berbasis Student Centered Learning dengan pendekatan discoveri pada pembelajaran Biologi sudah memenuhi indikator pencapaian yang diharapkan yaitu 70\% lebih siswa memperoleh nilai 73 dengan nilai rata-rata kelas 76,31. Hasil belajar siklus II mengalami peningkatan dari 56,25\% menjadi 87,5\% yang memperoleh nilai $>73$.

\section{Kemajuan Penelitian antar Siklus}

Untuk melihat perubahan peningkatan hasil belajar pada tiap siklus disajikan dalam tabel berikut :

Tabel 5. Peningkatan Hasil Belajar Siswa Siklus I dan Siklus II

\begin{tabular}{llll}
\hline \multirow{2}{*}{ Siklus } & \multicolumn{2}{c}{ Persentase Jumlah siswa } & Nilai Rata- \\
\cline { 2 - 3 } & Nilai $>75($ Nilai $\geq$ & Nilai $\leq 75($ Nilai $<75)$ & rata Hasil \\
\hline
\end{tabular}




\begin{tabular}{cccc}
\hline & $75)$ & & Belajar \\
\hline I & $56,25 \%$ & $43,76 \%$ & 71,47 \\
II & $87,5 \%$ & $12,5 \%$ & 76,31 \\
\hline
\end{tabular}

Hasil belajar siswa dari siklus I ke siklus II terus meningkat dengan signifikan dari rata-rata 71,47 menjadi 76,31. Persentase siswa yang lulus dengan nilai $\geq 75$ meningkat dari $56,25 \%$ menjadi $87,5 \%$. Peningkatan hasil belajar siswa dari siklus I ke siklus II dapat dilihat pada gambar berikut :

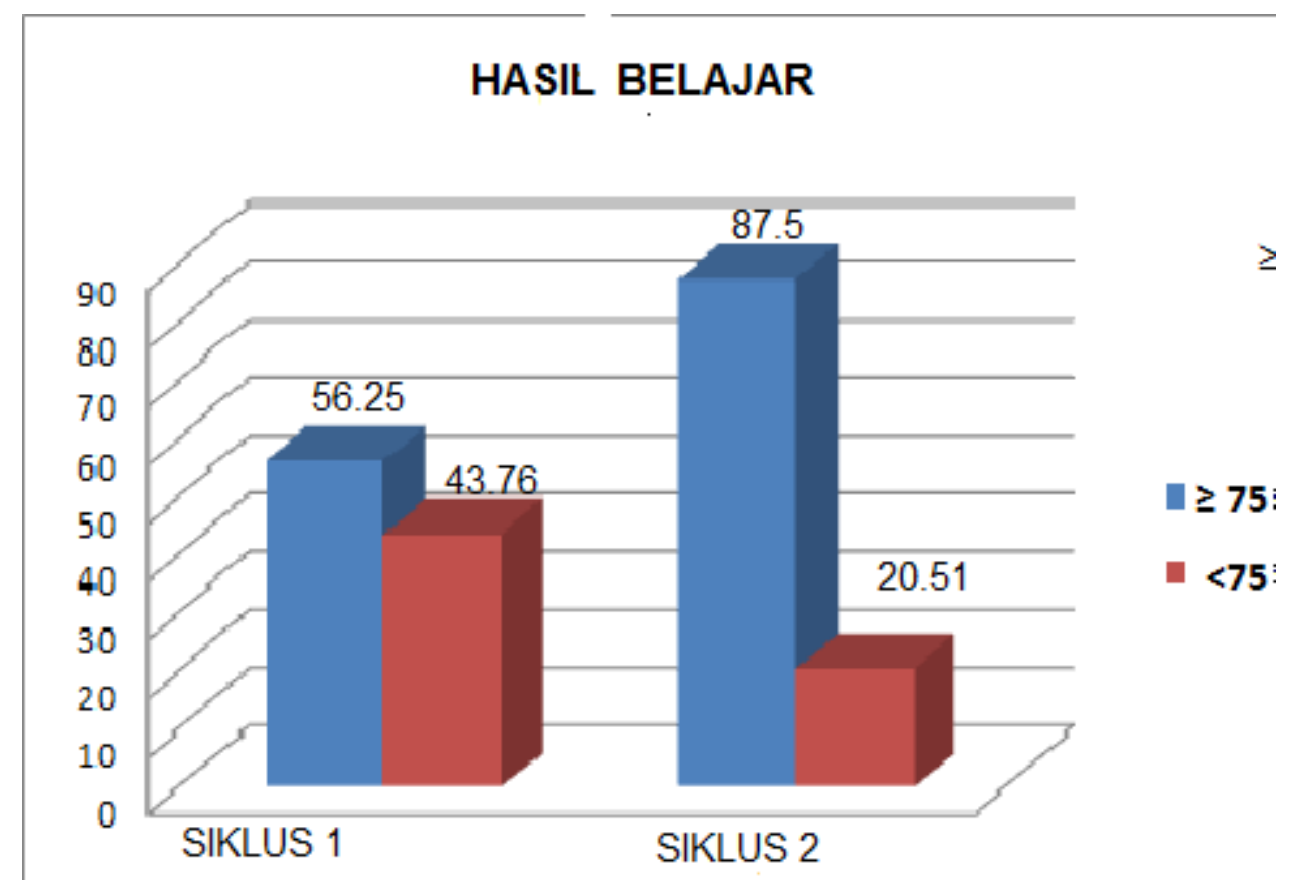

Gambar 4.1. Peningkatan Hasil Belajar Siswa pada Siklus I ke Siklus II

Peningkatan hasil belajar siswa dari siklus I ke siklus II, menunjukkan perbaikan tindakan kelas yang dilakukan pada siklus II mampu meningkatkan hasil belajar siswa. Dari gambar 3 terlihat bahwa terjadi peningkatan hasil belajar Biologi melalui penggunaan Lembar Kerja Siswa berbasis Student Centered Learning dengan menggunakan pendekatan saintifik discoveri yang cukup signifikan.

Dalam proses pembelajaran dengan pendekatan saintifik discoveri guru memberikan arahan dan bimbingan pada saat siswa menjalani semua tahapan pendekatan saintifik discoveri membuat siswa semakin terarah dalam merumuskan masalah dan pada akhirnya 
siswa menjadi paham dengan materi pembelajaran dilakukan piningkatan tindakan pada silkus II. Pada siklus II, guru lebih sering melakukan pengawasan dengan berkeliling untuk memperhatikan, mengawasi dan mengamati pembelajaran yang dilakukan siswa dengan menggunakan Lembar Kerja Siswa berbasis Student Centered Learning..

Pemberian latihan dan tugas dalam penelitian ini bertujuan untuk melatih kemampuan siswa agar siswa semakin paham dengan materi yang diberikan. Dari siklus I ke siklus II, guru meningkatkan tindakan pemberian latihan dan tugas ini disambut dengan baik oleh siswa dengan berlomba-lomba untuk dapat menyelesaikan soal dan kasus yang dijadikan persoalan. Tindakan perbaikan dari pemberian latihan ini membuat suasana pembelajaran dengan penggunaan Lembar Kerja Siswa berbasis Student Centered Learning melalui penggunaan saintifik discoveri menjadi lebih interaktif, siswa menjadi antusias bertanya dan menjawab untuk mencari solusi permasalahan.

Pencapaian hasil belajar siswa sudah sesuai dengan yang diharapkan tidak lepas dari peran pengawasan guru dalam proses pembelajaran. Karena guru juga merupakan salah satu komponen yang mempengaruhi hasil belajar siswa. Pada siklus II terjadi perubahanperubahan yang baik, seperti hasil belajar siswa menjadi optimal, semangat belajar siswa meningkat, siswa aktif dalam pembelajaran, dan suasana pembelajaran menjadi lebih kondusif. Sehingga melalui penggunaan Lembar Kerja Siswa berbasis Student Centered Learning dengan pendekatan saintifk discoveri siswa terlibat lebih aktif dalam proses pembelajaran dan mudah memahami materi pembelajaran.

Pada siklus II, guru berusaha menstimulir kemampuan siswa dalam proses pembelajaran yaitu dengan memberikan kebebasan dan dukungan dalam pembelajaran dengan pengawasan dan bimbingan. Selalu memotivasi kepercayaan diri siswa dalam memecahkan masalah yang dihadapi. Mengupayakan menempatkan siswa sebagai subyek belajar yang aktif, dengan memberikan latihan-latihan atau kasus-kasus. Selain meningkatkan keaktifan siswa dalam proses pembelajaran, faktor lain yang mendorong tercapainya ketuntasan belajar kognitif siswa karena siswa sudah memiliki pengalaman belajar melalui penggunaan Lembar Kerja Siswa berbasis Student Centered Learning dengan pendekatan saintifik discoveri sehingga dengan mudah memahami materi yang diberikan. 


\section{DAFTAR PUSTAKA}

Arsyad, Azhar. (2011). Media Pembelajaran. Jakarta: Raja Grafindo Persada.

Arikunto, Suharsimi. (1999). Dasar-dasar Evaluasi Pendidikan. Jakarta: Rineka Cipta.

Dimyati dan Mudjiono. (1999). Belajar dan pembelajaran. Jakarta: Rineke Cipta.

Djamarah, Syaiful Bahri dan Aswan Zain, (2006). Strategi Belajar Mengajar, Jakarta, Rineka Cipta.

Gulo, W. (2008). Strategi Belajar Mengajar. Jakarta: Grasindo

Hamalik, Oemar.( 2008). Proses Belajar Mengajar. Jakarta: Bumi Aksara.

Kunandar. (2007). Guru Profesional : Implementasi Kurikulum Tingkat Satuan

Pendidikan (KTSP dan Sukses dalam Sertifikasi Guru). Jakarta : Raja Grafindo Persada.

Nana Sudjana dan Ahmad Rivai. (2001). Teknologi Pengajaran. Bandung: Sinar Baru Algensindo.

Nasrun Harahap, dkk. (2002). Teknik Penilaian Hasil Belajar. Jakarta: Bulan Bintang.

Poerwadarminta, WJS. (2002). Kamus Umum Bahasa Indonesia. Jakarta: Balai Pustaka.

Roestiyah. (2008). Strategi Belajar Mengajar. Jakarta: Rineka Cipta

Sadiman AS Raharjo, Haryino, A. Dan Raharjo, (1986). Media Pendidikan, Pengertian, Pengembangan dan Pemanfaatannya. Jakarta: PT Grafindo Persada.

Sanjaya, Wina. (2011). Strategi Pembelajaran. Jakarta: Kencana Prenada Media Group.

Sukamadinata, Nana Syaodih. (1997).Pengembangan kurikulum. Bandung: Remaja Rosdakarya.

Syaiful Sagala. ( 2007). Konsep dan Makna Pembelajaran. Bandung: Alfabeta. 